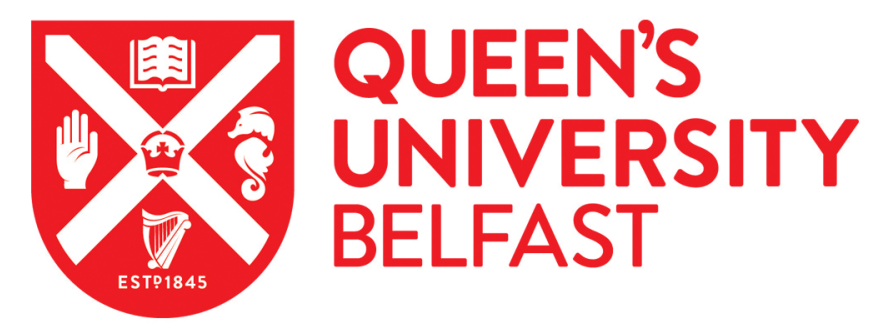

\title{
Are food-related perceptions associated with meal portion size decisions? A cross-sectional study
}

Spence, M., Stancu, V., Dean, M., Livingstone, M. B. E., Gibney, E. R., \& Lähteenmäki, L. (2016). Are foodrelated perceptions associated with meal portion size decisions? A cross-sectional study. Appetite, 103: https://doi.org/10.1016/j.appet.2016.04.039

\section{Published in:}

Appetite

\section{Document Version:}

Peer reviewed version

Queen's University Belfast - Research Portal:

Link to publication record in Queen's University Belfast Research Portal

Publisher rights

(C) 2016 Elsevier Ltd. This manuscript version is made available under the CC-BY-NC-ND 4.0 licensehttp://creativecommons.org/licenses/by$\mathrm{nc}-\mathrm{nd} / 4.0 /$,which permits distribution and reproduction for non-commercial purposes, provided the author and source are cited.

\section{General rights}

Copyright for the publications made accessible via the Queen's University Belfast Research Portal is retained by the author(s) and / or other copyright owners and it is a condition of accessing these publications that users recognise and abide by the legal requirements associated with these rights.

Take down policy

The Research Portal is Queen's institutional repository that provides access to Queen's research output. Every effort has been made to ensure that content in the Research Portal does not infringe any person's rights, or applicable UK laws. If you discover content in the Research Portal that you believe breaches copyright or violates any law, please contact openaccess@qub.ac.uk. 


\section{Accepted Manuscript}

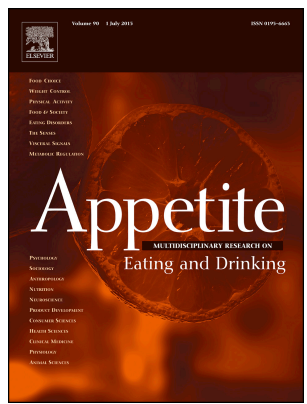

Are food-related perceptions associated with meal portion size decisions? A crosssectional study

Michelle Spence, Violeta Stancu, Moira Dean, M. Barbara E. Livingstone, Eileen R. Gibney, Liisa Lähteenmäki

PII: S0195-6663(16)30168-4

DOI: 10.1016/j.appet.2016.04.039

Reference: $\quad$ APPET 2976

To appear in: Appetite

Received Date: 19 February 2016

Revised Date: 29 April 2016

Accepted Date: 30 April 2016

Please cite this article as: Spence M., Stancu V., Dean M., Livingstone M.B.E., Gibney E.R. \& Lähteenmäki L., Are food-related perceptions associated with meal portion size decisions? A crosssectional study, Appetite (2016), doi: 10.1016/j.appet.2016.04.039.

This is a PDF file of an unedited manuscript that has been accepted for publication. As a service to our customers we are providing this early version of the manuscript. The manuscript will undergo copyediting, typesetting, and review of the resulting proof before it is published in its final form. Please note that during the production process errors may be discovered which could affect the content, and all legal disclaimers that apply to the journal pertain. 


\section{Are food-related perceptions associated with meal portion size decisions? A cross-sectional study}

Michelle Spence ${ }^{\mathrm{a}}$, Violeta Stancu ${ }^{\mathrm{b}}$, Moira Dean ${ }^{\mathrm{a}^{*}}$, M Barbara E Livingstone ${ }^{c}$, Eileen R Gibney ${ }^{\mathrm{d}}$, Liisa Lähteenmäki ${ }^{\text {b }}$

'Institute for Global Food Security, School of Biological Sciences, Queen's University Belfast, Belfast, BT9 5AG, UK.

${ }^{\mathrm{b}}$ MAPP Centre, Aarhus BSS, Aarhus University, Bartholins Allé 10, DK-8000 Aarhus C.

${ }^{\mathrm{c}}$ Northern Ireland Centre for Food and Health (NICHE), University of Ulster, Coleraine, BT52 1SA, UK.

${ }^{d}$ UCD Institute of Food and Health, School of Agriculture and Food Science, UCD, Dublin 4, Republic of Ireland.

Email addresses:

MS: m.s.spence@qub.ac.uk

VS:VIOST@mgmt.au.dk

MD:moira.dean@qub.ac.uk

MBEL: mbe.livingstone@ulster.ac.uk

ERG: eileen.gibney@ucd.ie

LM: LIISAL@mgmt.au.dk

*Corresponding author: $\operatorname{Dr}$ Moira Dean, Institute for Global Food Security, School of Biological Sciences, Queen's University Belfast, Belfast BT9 5AG, UK. Phone: $+44(0) 289097$ 6561; fax: +44(0)289097 6513; e-mail: moira.dean@qub.ac.uk 


\section{Abstract}

2 The purpose of this study was to test a comprehensive model of meal portion size

3 determinants consisting of sociodemographic, psychological and food-related

$4 \quad$ variables, whilst controlling for hunger and thirst.

5 Using cross-sectional nationally representative data collected in 2075 participants

6 from the Island of Ireland (IoI) and Denmark (DK), eight separate hierarchical

7 multiple regression analyses were conducted to examine the association between

8 food-related variables and meal portion size (i.e. pizza, vegetable soup, chicken salad

9 and a pork meal) within each country. Stepwise regressions were run with physiological control measures (hunger and thirst) entered in the first step, sociodemographic variables (sex, age, body mass index (BMI)) in the second step; psychological variables (cognitive restraint, uncontrolled eating, emotional eating, general health interest (GHI)) in the third step and food-related variables (expected fillingness, liking, expected healthfulness, food familiarity) in the fourth step.

Sociodemographic variables accounted for $2-19 \%$ of the variance in meal portion sizes; psychological variables explained an additional 3-8\%; and food-related variables explained an additional 2-12\%. When all four variable groups were included in the regression models, liking and sometimes expected healthfulness was positively associated with meal portion size. The strongest association was for liking, which was statistically significant in both countries for all meal types. Whilst expected healthfulness was not associated with pizza portion size in either country, it was positively associated with meals that have a healthier image (vegetable soup; chicken

23 salad and in IoI, the pork meal). 
In conclusion, after considering sociodemographic and psychological variables, and the food-related variables of liking and expected healthfulness, there may be little merit in manipulating the satiating power, at least of these type of meals, to maintain or promote weight loss.

Keywords: Meal portion size; psychological variables; expected fillingness; expected healthfulness; food liking; food familiarity.

\section{Introduction}

Excess energy intake and weight gain have been attributed to an increase in food portion sizes (for a recent critical review, see Benton, 2015). Numerous experimental studies in both laboratory and natural social settings (e.g. restaurants) have demonstrated that increasing the portion size served leads to increased energy intake at single meals (Rolls, Morris, \& Roe, 2002) and over the course of several days (Jeffery et al., 2007; Rolls, Roe, \& Meengs, 2006; Rolls, Roe, \& Meengs, 2007). This 'portion size effect' has been observed across a variety of food types, among diverse study populations, and in different social contexts (for a recent meta-analysis of the literature, see Zlatevska, Dubelaar, \& Holden, 2014). Accordingly, it has been suggested (Birch, McPhee, Shoba, Steinberg, \& Krehbiel, 1987) that there is a tendency for people to 'plate clean' when eating larger portions.

Interestingly, recent studies in free-living eating scenarios additionally demonstrate that the majority of self-selected meals tend to be consumed in their entirety, with the amount eaten often planned and anticipated in advance of eating (Fay et al., 2011;

Hinton et al., 2013). Evidence for meal planning also comes from a detailed

GHI: General Health Interest; BMI: Body Mass Index; IoI: Island of Ireland; DK, Denmark. 
qualitative analysis of the discourse of attitudes expressed by focus group participants' towards point-of-purchase interventions aimed at portion size (Vermeer, Steenhuis, \& Seidell, 2010) and more recently, from measuring pre-meal intended consumption in males served standard or larger portion sizes (i.e. a 'pre-consumption portion size effect') (Robinson, Te Raa, \& Hardman, 2015). Therefore, rather than solely focusing on within meal processes (e.g. satiation, distraction, atmospherics, and socialising etc.) which influence portion size consumption (Hellstrom et al. 2004;

Wansink, 2004), meal size could also be governed by a period of cognitive activity (planning) that occurs before a meal begins (Wilkinson et al., 2012).

$$
\text { Studies reveal that self-selected or typical portion sizes of various foods are }
$$
affected by a number of sociodemographic (i.e. body mass index (BMI) (Burger, Kern \& Coleman, 2007; Lewis et al., 2015), sex (Burger et al., 2007; Lewis et al., 2015; Brunstrom, Rogers, Pothos, Calitri, \& Tapper, 2008)), and psychological (i.e. cognitive restraint, uncontrolled eating, emotional eating (Brunstrom et al., 2008a; Lemmens et al., 2010; Lewis et al., 2015; Spence et al., 2013; Wilkinson et al., 2012;) variables. Food-related variables are also found to be important; for example, expected satiety (for a recent review see Forde, Almiron-Roig, \& Brunstrom, 2015), liking (Brunstrom \& Shakeshaft, 2009b; Lewis et al., 2015), food familiarity (Brogden \& Almiron-Roig, 2010; Brunstrom, Shakeshaft, \& Scott-Samuel, 2008b), and expected healthfulness (Faulkner et al., 2014; Spence et al., 2013; Wansink \& Chandon, 2006). However, to date, there is limited and mixed evidence for the majority of these effects and the role of each variable relative to one another in meal portion size decisions remains largely unknown. Indeed, a recent review (English, Lasschuijt, \& Keller, 2015) of the mechanisms underlying the portion size effect concludes that we need larger studies in more representative samples which 'integrate 
measures of individual subject-level differences with assessment of food-related characteristics'.

Accordingly, the present study tested a comprehensive model of meal portion size determinants consisting of sociodemographic, psychological and food-related variables, whilst controlling for hunger and thirst, in a cross-sectional, nationally representative sample of adults living in the Island of Ireland (IoI) and Denmark (DK). Given the wide age range of participants being recruited for the present study and the documented potential of this sociodemographic to impact dietary intake and eating habits (Wakimoto \& Block, 2001), we also considered age as a sociodemographic variable of interest. Likewise, given previous positive associations of the General Health Interest (GHI) scale with healthful food choices (Roininen, Lahteenmaki, \& Tuorila, 1999) and portion control strategy use (Spence et al., 2015), GHI was included as another psychological variable of interest.

\section{Material and Methods}

\section{Survey and sample description}

The data reported here were collected as part of an analytical cross-sectional survey investigating various psychological, social and behavioral factors related to portion control in a quota-controlled nationally representative sample of adults living in the IoI and DK. The measures used in these analyses were common in both countries. The IoI and DK surveys had been piloted on a sample of $n=30$ and $n=200$ participants, respectively, and, underwent minor changes before large scale data collection. Data collection for the IoI survey has been described in detail previously (Spence et al., 2015). In brief, interviews were conducted face-to-face in-home, on $31^{\text {st }} \mathrm{July}$ to $7^{\text {th }}$ September 2012 , by marketing company researchers using computer-assisted personal interviewing. The sample $(\mathrm{n}=1012)$ was quota-controlled in terms of sex, 
age, social class and area of residence to match the known demographics of the population. On average interviews lasted approximately 40 minutes and participants received $£ 5 / € 6.50$ remuneration for completing the interview.

Data for the DK study were collected between $9^{\text {th }}$ to $31^{\text {st }}$ July 2012 using an online survey designed in the Qualtrics (http://www.qualtrics.com/) software program. In collaboration with YouGov (a market research agency), 3303 individuals were recruited from an established online panel consisting of consumers with diverse demographic characteristics. Of the 1109 participants that completed the survey (response rate $=34 \%$ ), 1063 pertained to the target group and formed the final sample. The sample was quota-controlled in terms of sex, age and region to match the known demographics of the population, with each participant claiming to be responsible to some extent for preparing and cooking their household's food. Participants received points which could be redeemed in the YouGov panel store as remuneration for their participation.

Demographic characteristics of the IoI and DK participants are described in Table 1. All participants provided informed consent verbally (IoI survey) or by agreeing to take part in the survey as members of an online panel (DK survey). The IoI study was conducted according to the guidelines laid down in the Declaration of Helsinki and approved by Queens University Belfast Ethical Committee. The Danish data collection was carried out according to ESOMAR guidelines.

\section{Questionnaire outline for common part of survey}

In order to control for current physiological state, we obtained a measure of how hungry or thirsty each participant was by using a seven-point semantic differential scale. End points were labelled "not hungry/thirsty at all" and "extremely hungry/thirsty". Participants then rated four types of meals (described below in the 
121 stimuli section) for expected fillingness, liking, expected healthfulness, and food

122 familiarity before selecting a meal portion size, and, completing several psychological

123 measures i.e. GHI, cognitive restraint, uncontrolled eating, and emotional eating.

124 Finally, sex, age, and self-reported height and weight were recorded. The latter two

125 measures were also used to compute BMI (weight in kilograms divided by square of

126 height in meters).

\section{Stimuli}

128 We selected four meals (three single component meals and one multi-component

129 meal) that are commonly eaten in both the IoI and DK and which would potentially

130 differ markedly in their healthfulness ratings; (1) pizza, (2) vegetable soup, (3)

131 chicken salad, and (4) a 'pork meal' consisting of pork fillet, potatoes, mixed

132 vegetables and optional salad. Test foods were digitally photographed in colour on a

133 white $23 \mathrm{~cm}$ bowl for soup and $24 \mathrm{~cm}$ plate for all other meals (placed on a white table)

134 next to reference objects that would provide a realistic idea of portion size (a fork,

135 knife or spoon and napkin). The pizza, vegetable soup, chicken salad and components

136 of the pork meal (pork fillet, potatoes, mixed vegetables, and salad) were each

137 photographed six times in increasing portion size; picture number one represented the

138 smallest portion size while picture six represented the largest portion size. Particular

139 care was taken to ensure that each photograph had been taken from the same angle

140 and distance above the plate, whilst maintaining a constant lighting condition. Pictures

141 of the largest meal portion sizes are shown in Figure 1.

142 Measures

143 Expected fillingness: Participants rated how filling they expected each type of test

144 meal to be on a 7-point Likert scale ranging from $1=$ "Not at all filling" to $7=$ 
"Extremely filling". We defined expected fillingness as "how long each type of meal will keep you feeling full”.

Liking: IoI participants rated their liking for each test meal on a 7-point Likert scale ranging from 1 = "I strongly dislike this type of food" to 7 = "I strongly like this type of food". In DK, liking was rated on a 7-point scale that can be directly translated as 1 $=$ "I do not like at all" to 7 = "I strongly like this type of food", as Danish expression for liking is expressed in a unipolar scale. This difference has implications for the means of the ratings (Tuorila et al., 2008), but as the country data were analysed separately, this should have no implications for the association between liking and meal portion size. Participants were advised to use a separate response option if they had never tasted the type of meal in question.

Expected healthfulness: Expected healthfulness of each type of test meal was measured on a 7-point Likert scale ranging from $1=$ "Not healthy at all" to "Extremely healthy".

Food familiarity: To confirm familiarity with the test meals, participants selected one of the following options in response to the question "How frequently have you eaten pizza/ vegetable soup/ chicken salad/ pork meal during the past year?": once a day, 56 times a week, 2-4 times a week, once a week, 1-3 times a month, less than once a month, or never. Responses were coded 1-7, so that high scores reflected high consumption frequency.

Meal portion size: Participants were asked to think of a typical type of pizza/ vegetable soup/ chicken salad/ pork meal which they could eat at home, and, were given the following instruction: "Imagine you're only having <pizza/ vegetable soup/ chicken salad/ pork fillet with potatoes and mixed vegetables (salad optional) $>$ for your dinner. How much would you eat?". Participants were asked to choose a 
photograph which most closely represented the amount that they would consume for their dinner at home. In the IoI study, participants viewed six (or seven if salad was chosen) A4 sheets with six portion size photographs (size: $8.0 \times 5.3 \mathrm{~cm}$ ) before making their selection known to the interviewer. The portion size photographs were presented in the same order to participants (pizza; vegetable soup; chicken salad; pork fillet; potatoes; mixed vegetables and salad). In the online DK survey, participants used the online arrow buttons (up and down) to increase or decrease the portion size. The test meals (pizza/vegetable soup/chicken salad/pork meal) were presented in a random order to participants while the meal components within the the pork meal (pork fillet; mixed vegetables; potatoes; and salad) were presented together on one plate and respondents could change the amount of each component; each component was presented on a constant position on the plate. For each meal, the initial portion size displayed on the screen to the participants was a random portion size of the test meal; for the pork meal the initial portion was a combination of random sizes of each one of the components.

General Health Interest: The importance of health in relation to food choice was measured using the GHI subscale of the Health and Taste Attitude Scales (Roininen, et al., 2001), with the modification that one item with the lowest factor loading was removed; "I do not avoid foods, even if they raise my cholesterol". All responses were coded on a 7-point Likert scale (ranging from 1 = "strongly disagree" to 7 = "strongly agree") and a mean score of the items was calculated, so that a higher scale score was indicative of greater GHI.

Cognitive restraint, emotional eating, and uncontrolled eating: Three aspects of current eating behavior were assessed by the Three-Factor Eating Questionnaire Revised 18 item version (TFEQ-R18; de Lauzon et al., 2004); cognitive restraint (6 
items), emotional eating ( 3 items) and uncontrolled eating ( 9 items). For the present study, we reformulated the response option for one item to match that used in a previous questionnaire (The Nutritional Epidemiology Group, Centre for Epidemiology and Biostatistics, University of Leeds, n.d.) to enable participants to more easily indicate the overall extent of their cognitive restraint. All responses were coded on a 4-point scale (1-4) and a summary scale score was calculated as a mean of the component items, so that higher scale scores were indicative of greater cognitive restraint, emotional eating, or uncontrolled eating. The response alternatives measured, e.g., how true, likely or frequent certain food control behaviors were, e.g., "I do not eat some foods because they make me fat".

\section{Data analysis}

In the first instance, portion size pictures of each meal or meal component were converted to their respective energy contents based upon back-of-pack nutritional labelling. For the multi-component pork meal, all of the component energy values were summed.

In analysing the data, a descriptive analysis was first performed to describe the variables (Table 2). Four-step hierarchical multiple regressions were then conducted to examine the association between food-related variables and meal portion sizes, using the energy content for each meal as the dependent variables. The independent variables were entered as groups; in step one the current perceived physiological state of hunger and thirst were entered to control for their possible impact on portion-size decisions, followed by sociodemographic variables (sex, age, and BMI) in step 2; psychological variables (cognitive restraint, uncontrolled eating, emotional eating, and GHI) in step 3; and finally, food-related variables (expected fillingness, liking, expected healthfulness, and food familiarity) in step 4. The reason for this order was 


\section{Results}

to start with factors that are likely to influence meal portion size decisions, but which cannot be changed (sociodemographic variables), then have the relatively stable psychological eating styles and in the final step add the stimuli-dependent variables that reflect an individuals' perception of specific types of foods.

As a slightly different pattern in explanatory variables was seen for IoI and DK separately, results are presented as cross-country regressions for each meal. For each regression, participants were excluded based upon two exclusion criteria. First, participants with a BMI $\leq 15(n=4)$ and $B M I \geq 45(n=14)$ were excluded. Second, the Mahalanobis distance procedure was used to identify and exclude multivariate outliers in each regression (Mahalanobis distance $\left.\chi^{2}(13)=>34, p<.001\right)$. As recommended by Field (Field, 2009), Pearson correlation coefficients and tolerance statistics were used to check for possible multicollinearity between predictor variables. Both collinearity diagnostics indicated that multicollinearity was not a concern (i.e. all correlation coefficients were less than 0.80 , all tolerance statistics were above 0.2 ). Furthermore, regression assumptions regarding normality, linearity and homoscedasticity were met. For each of the eight models in Table 3, we report the explained variance $\left(\mathrm{R}^{2}\right)$ for the first regression step and the change of explained variance $\left(\Delta \mathrm{R}^{2}\right)$ after the addition of steps two, three and four. For the final four-step models in Table 4, we report the standardised regression coefficients for each variable $(\beta)$ and the adjusted variance explained for the final models $\left(R^{2}{ }_{a d j}\right)$. All analyses were conducted using IBM SPSS Statistics for Windows version 21.0 (IBM Corporation, Armonk, NY, USA), with a p-value $p \leq 0.05$ considered to be significant.

\section{Descriptive statistics}


Mean (SD) response, possible mean range, and internal reliability values for independent variables by country are presented in Table 2. Participants in the DK sample were slightly older and had a higher BMI than participants in the IoI sample.

In relation to both the pizza and pork meal, findings showed that DK (compared to IoI) scored (a) significantly higher for meal portion size, liking, and food familiarity; and (b) significantly lower on expected healthfulness. In contrast, the portion size of the chicken salad in DK was significantly lower than the IoI, and the following foodrelated variables were scored significantly higher: expected fillingness; liking; and food familiarity. The vegetable soup portion size was comparable between countries, with DK scoring significantly higher on expected healthfulness and food familiarity than IoI, and significantly lower on expected fillingness. In relation to the psychological variables, DK had higher GHI and, lower emotional eating scores than IoI.

\section{Regression Analysis: Predictors of Meal Portion Size}

After controlling for current physiological state in step 1, the hierarchical multiple regressions revealed that each additional variable group (step) significantly improved all models (Table 3). Across the models, the sociodemographic variable group accounted for $2-19 \%$ of the variance in meal portion size and adding the psychological variable group to the regression model explained an additional 3-8\% of the variation. Finally, the further addition of the food-related variable group explained an additional $2-12 \%$ of the variation in meal portion size. Together, the four variable groups accounted for $14-43 \%$ of the variance in meal portion size; with the percentage of explained variance being largest for the portion size of the pizza in IoI (Table 4).

In the group of sociodemographic variables (final regression models in Table 4), sex was consistently and significantly associated with each meal portion size in both 
countries, with men scoring higher for meal portion size than women. A younger age and higher BMI were also significantly associated with a larger meal portion size in the DK sample, whereas age was only positively associated with pizza meal portion size in the IoI sample.

In the group of psychological variables (final regression models in Table 4), uncontrolled eating was consistently and significantly associated with each meal portion size in both countries, with higher uncontrolled eating scores being associated with greater portion size. A lower cognitive restraint was also significantly associated with a greater portion size of each meal in the DK sample, whereas cognitive restraint was only negatively associated with the IoI vegetable soup portion size. Emotional eating (IoI only) and GHI (IoI and DK) were positively associated with portion size in three out of the eight meal models.

Of the food-related variables (final regression models in Table 4), liking and sometimes expected healthfulness were positively associated with meal portion size. The strongest association was for liking, which was statistically significant in both countries for all meal types. Whilst expected healthfulness was not associated with pizza portion size in either country, it was positively associated with meals that have a healthier image (vegetable soup; chicken salad and in IoI, the pork meal). Expected fillingness and food familiarity, on the other hand, were only significantly associated with IoI pizza portion size.

\section{Discussion}

To our knowledge this is the first study to examine a comprehensive framework of contributors to meal portion size in a large representative sample of adults. Specifically, we studied the relative effects of both individual-level variables (i.e. sociodemographic and psychological) and food-related variables on meal portion size 
in a cross-sectional study of 2075 participants living in two coutries with different cultures but similar dishes. Our models showed that, apart from uncontrolled eating, psychological contributors to meal portion size are somewhat different between the IoI and DK. Furthermore, not all food-related variables which appeared important for portion size in previous studies were significantly associated with meal portion size.

Sex was the strongest sociodemographic contributor to meal portion size, which is not surprising given the higher energy needs of men, and supports the external validity of the chosen method to study portion size decisions. These observed differences in portion size between men and women have been found in previous studies for some, but not for all food types (Brustrom et al., 2008a; Burger et al., 2007). For example, using real food items, male students served themselves larger portions of high-energy, high-fat and high-carbohydrate foods than female students (and comparable portions in the corresponding lower categories) (Burger et al., 2007), and a study assessing usual portion size using a computer programme found males reported consuming larger portions in half of their test foods (three main meals and three side dishes), compared to females (Brunstrom et al., 2008a). Similarly, in another computer based study, Lewis et al. (2015) found that males had larger personal norms for portion size when compared to females. These findings are consistent with the notion that males have higher energy requirements which can be fulfilled through consumption of larger portion sizes.

An interesting finding from this study is the absence of a positive relationship between BMI and all meal portion sizes in the IoI sample and the presence of this positive relationship in the DK sample. While relationships between BMI and portion size are generally not observed in dietary surveys, experimental studies which have explored the relationship between BMI and typical self-selected portion size have 
reported equivocal results (e.g. a positive relationship (Burger et al., 2007; Lewis et al., 2015) vs no relationship (Brunstrom et al., 2008a; Wilkinson et al., 2012).

Previous research has shown that there may be bias in self-report data on food intake, with a greater magnitude of under-reporting of energy intake in obese individuals (Prentice et al., 1986). It is possible that the same underreporting may account for the lack of a relationship between BMI and meal portion size in our IoI sample, however, evidence for this effect remains to be shown. The mode of survey administration (i.e. interviewer-administered in IoI vs computer-administered in DK) may have made participants more reluctant to answer truthfully in the IoI due to greater concerns about the negative impression that their response may give.

Overall, uncontrolled eating (IoI and DK) was the strongest psychological contributor to meal portion size, followed by cognitive restraint in DK and emotional eating in IoI. Even though it would seem intuitive that higher levels of uncontrolled eating and lower levels of cognitive restraint would be associated with larger portion sizes, most previous studies have not shown clear effects of these types of variables on food portion size (Brunstrom et al., 2008a; Lewis et al., 2015; Wilkinson et al., 2012). Consistent with previous reports (Brunstrom et al., 2008a; Lewis et al., 2015), we did find that lower cognitive restraint scores were significantly associated with larger portion size, but likewise, we note that we cannot fully exclude the possibility of reporting biases. Furthermore, emotional eating on the IoI was related to a larger portion size of pizza which is typical of high-energy dense foods (Gibson, 2012), but surprisingly, it was also associated with vegetable soup and chicken salad which are low-energy dense foods that were considered as healthy meal options in this study, and thereby could not be considered as typical targets in emotional eating (Raaijmakers, Gevers, Teuscher, Kremers, \& van Assema, 2014). In the IoI sample 
the high responsiveness to emotional eating seemed to be linked to an increased portion size across a wide range of foods, whereas in the DK sample the link was not found with these foods. In general the Danish repondents scored low on the emotional eating scale, which may partly be a result of how food is used in response to emotional stress, and also which kinds of foods are used (e.g. snack vs meals).

Perhaps unsuprisingly and in accord with previous studies (Brunstrom et al., $2009 \mathrm{~b}$ ) is the observation that liking was a strong positive food-related contributor to meal portion size. Expected healthfulness, consistent with previous studies (Faulkner et al., 2014; Wansink \& Chandon, 2006), was positively associated with meal portion size. Interestingly, this association was only present in meals with a healthier image (vegetable soup; chicken salad and in IoI, the pork meal) and no association was found with pizza portion size. Furthermore, GHI was linked to higher portion sizes, but only in these "healthy" foods. For those respondents who found health as an important factor in their food choices, the healthy image seems to work as a licence to eat more (Poelman, Vermeer, Vyth, \& Steenhuis, 2013). Alternatively, those who are more health conscious may have a better understanding of the energy contribution of each meal: even the largest portion size is well below those derived from larger portions of pizza or even the multi-component meal. In future it would be interesting to repeat the study with products that differ in their health image, but have the same energy density; however, this is not the case in most real world foods.

Of particular note, is our finding that expected fillingness is not an important determinant of meal portion size. This finding is at odds with those of previous studies (Forde, Alexander, Thaler, Martin, \& Brustrom, 2011; Brunstrom \& Shakeshaft, 2009b; Brunstrom \& Rodgers 2009a; Wilkinson, 2012;), who have systematically explored computer-based measures of expected satiety relative to liking, to 
demonstrate that expected satiety is a better predictor of portion size. Although more and less sensitive measures of expected fillingness have been used in previous research studies (see Forde, Almiron-Roig, \& Brunstrom, 2015 for a recent review), fillingness scales, similar to that used in the current study, have been shown to predict energy intake. The current finding is suggests that after considering individual level differences, liking and expected healthfulness, there may be little merit in manipulating the satiating power, at least of these type of meals, to maintain or promote weight loss. However, the extent to which this analysis extends to all meal types, especially those eaten outside of the home environment, remains unclear. Apart from the high amount of unexplained variance, which may be improved by adding environmental and context specific factors, there are other limitations to note. Firstly, some of our survey's self-report measures (e.g. about weight, height and portion size) may have been regarded by participants as sensitive and thus prone to social desirability response bias. This bias in portion size report may also have been further compounded by our use of pictures in the measure of meal portion size. This may have resulted in underestimation and/or overestimation of meal portion size, however, it has been recently shown that photographic meal data can be a valid and useful measure of 'real-life' portion size (Hinton et al., 2013). The different modes of survey administration in DK and IoI may also limit comparability of results. Another limitation associated with this type of study was that the composition of our test meals may not be reflective of typical meals. For example, IoI consumers may not typically consume pizza in isolation but may instead choose to add salad or chips for a full meal. Nevertheless, many of these flaws are a result of issues inherent in studying a large sample size and/or exploring contributors to meal portion size. 
Despite these limitations, a major strength of the current study is that it

394

395 encompassed a large sample size which was representative of both IoI and DK in terms of age, sex, social class (IoI only) and area of residence. This sample was therefore ideal for assessing the relationship between food-related variables (e.g. expected satiety) and meal portion size, relative to individual-level variables (e.g. BMI, age, cognitive restraint). Future research could examine the relationship between these variables and other meals (e.g. healthy vs less healthy) and snacks in different cultural contexts.

\section{Conclusions}

After considering sociodemographic and psychological variables (the latter of which may be culturally specific), and the food-related variables of liking and expected healthfulness, there may be little merit in manipulating the satiating power, at least of these type of meals, to maintain or promote weight loss.

\section{Competing interests}

The authors declare that they have no competing interests.

\section{Authors' contributions}
All authors participated in the design of the study. VS and MS carried out the statistical analyses and MS and MD drafted the manuscript. All authors contributed to the manuscript by modifying, commenting and reviewing the text, and approving the final manuscript submitted for publication.

\section{Acknowledgements}

This material is based upon works supported by safefood, The Food Safety Promotion Board, under Grant No. 07-2010, and the SensWell Project, funded by the Danish Strategic Research Council. 


\section{References}

418 1. Benton, D. (2015). Portion size: what we know and what we need to know. Critical Reviews in Food Science and Nutrition, 55(7), 988-1004.

420

421

422

423

424

2. Birch, L. L., McPhee, L., Shoba, B., Steinberg, L., \& Krehbiel, R. (1987). “Clean up your plate": effects of child feeding practices on the conditioning of meal size. Learning and motivation, 18(3), 301-317.

3. Brogden, N., \& Almiron-Roig, E. (2010). Food liking, familiarity and expected satiation selectively influence portion size estimation of snacks and caloric beverages in men. Appetite, 55(3), 551-555.

4. Brunstrom, J. M., \& Rogers, P. J. (2009a). How Many Calories Are on Our Plate? Expected Fullness, Not Liking, Determines Meal-size Selection. Obesity, 17(10), 1884-1890.

6. Brunstrom, J. M., Rogers, P. J., Pothos, E. M., Calitri, R., \& Tapper, K. (2008a). Estimating everyday portion size using a 'method of constant stimuli': in a student sample, portion size is predicted by gender, dietary behaviour, and hunger, but not BMI. Appetite, 51(2), 296-301.

7. Brunstrom, J. M., \& Shakeshaft, N. G. (2009b). Measuring affective (liking) and non-affective (expected satiety) determinants of portion size and food reward. Appetite, 52(1), 108-114.

7. Brunstrom, J. M., Shakeshaft, N. G., \& Scott-Samuel, N. E. (2008b). Measuring 'expected satiety' in a range of common foods using a method of constant stimuli. Appetite, 51(3), 604-614.

8. Burger, K. S., Kern, M., \& Coleman, K. J. (2007). Characteristics of self-selected portion size in young adults. Journal of the American Dietetic Association, 107(4), 611-618. 
9. de Lauzon, B., Romon, M., Deschamps, V., Lafay, L., Borys, J. M., Karlsson, J., et al. (2004). The Three-Factor Eating Questionnaire-R18 is able to distinguish among different eating patterns in a general population. The Journal of nutrition, 134(9), 2372-2380.

10. English, L., Lasschuijt, M., \& Keller, K. L. (2015). Mechanisms of the portion size effect. What is known and where do we go from here? Appetite, 88, 39-49.

11. Faulkner, G. P., Pourshahidi, L. K., Wallace, J. M., Kerr, M. A., McCaffrey, T. A., \& Livingstone, M. B. (2014). Perceived 'healthiness' of foods can influence consumers' estimations of energy density and appropriate portion size. International journal of obesity, 38(1), 106-112.

12. Fay, S. H., Ferriday, D., Hinton, E. C., Shakeshaft, N. G., Rogers, P. J., \& Brunstrom, J. M. (2011). What determines real-world meal size? Evidence for premeal planning. Appetite, 56(2), 284-289.

13. Field, A. (2009). Discovering statistics using SPSS (3rd ed.). London: Sage.

14. Forde, C. G., Almiron-Roig, E., \& Brunstrom, J. M. (2015). Expected satiety: application to weight management and understanding energy selection in humans. Current obesity reports, 4(1), 131-140.

15. Forde, C. G., Alexander, E., Thaler, T., Martin, N., \& Brunstrom, J. M. (2011). Expectations of satiation and satiety are a better predictor of self-selected portion size than liking [Abstract]. Appetite. 57, 558.

16. Gibson, E. L. (2012). The psychobiology of comfort eating: implications for neuropharmacological interventions. Behavioural pharmacology, 23(5-6), 442460.

17. Hellstrom, P. M., Geliebter, A., Naslund, E., Schmidt, P. T., Yahav, E. K., Hashim, S. A., et al. (2004). Peripheral and central signals in the control of eating 
467

468

469

470

471

472

473

474

475

476

477

478

479

480

481

482

483

484

485

486

487

488

489

490

in normal, obese and binge-eating human subjects. The British journal of nutrition, 92, S47-57.

18. Hinton, E. C., Brunstrom, J. M., Fay S. H., Wilkinson, L.L., Ferriday, D., Rogers, P. J., et al. (2013). Using photography in 'The Restaurant of the Future'. A useful way to assess portion selection and plate cleaning? Appetite, 63, 31-35.

19. Jeffery, R. W., Rydell, S., Dunn, C. L., Harnack, L. J., Levine, A. S., Pentel, P. R., et al. (2007). Effects of portion size on chronic energy intake. The international journal of behavioral nutrition and physical activity, 4, 27.

20. Lemmens, S. G., Born, J. M., Rutters, F., Schoffelen, P. F., Wouters, L., \& Westerterp-Plantenga, M. S. (2010). Dietary restraint and control over "wanting" following consumption of “forbidden” food. Obesity, 18(10), 1926-1931.

21. Lewis, H. B., Forwood, S. E., Ahern, A. L., Verlaers, K., Robinson, E., Higgs, S., et al. (2015). Personal and social norms for food portion sizes in lean and obese adults. International journal of obesity, 39(8), 1319-1324.

22. Poelman, M. P., Vermeer, W. M., Vyth, E. L., \& Steenhuis, I. H., (2013). I don't have to go to the gym because I ate very healthy today: The development of a scale to assess diet-related compensatory health beliefs. Public Health Nutrition, 16, 267-73.

23. Prentice, A. M., Black, A. E., Coward, W. A., Davies, H. L., Goldberg, G.R., Murgatroyd, P. R., et al. (1986). High levels of energy expenditure in obese women. British medical journal (Clinical research ed.), 292(6526), 983-987.

24. Raaijmakers, L. G., Gevers, D. W., Teuscher, D., Kremers, S. P., \& van Assema, P. (2014). Emotional and instrumental feeding practices of Dutch mothers regarding foods eaten between main meals. BMC public health, 14, 171. 
491 25. Robinson, E., Te Raa, W., \& Hardman, C. A. (2015). Portion size and intended

492 consumption. Evidence for a pre-consumption portion size effect in males?

493 Appetite, 91, 83-89.

494 26. Roininen, K., Lähteenmäki, L., \& Tuorila, H. (1999). Quantification of consumer 495 attitudes to health and hedonic characteristics of foods. Appetite, 33(1), 71-88.

496 27. Roininen K., Tuorila H., Zandstra E.H., de Graaf, C., Vehkalahti K., Stubenitsky

497 K., et al. (2001). Differences in health and taste attitudes and reported behaviour

498 among Finnish, Dutch and British consumers: a cross-national validation of the

$499 \quad$ Health and Taste Attitude Scales (HTAS). Appetite, 37(1), 33-45.

500 28. Rolls, B. J., Morris, E. L., \& Roe, L. S. (2002). Portion size of food affects energy

501 intake in normal-weight and overweight men and women. The American Journal of

$502 \quad$ Clinical Nutrition, 76(6), 1207-1213.

503 29. Rolls, B. J., Roe, L. S., \& Meengs, J. S. (2006). Larger portion sizes lead to a

504 sustained increase in energy intake over 2 days. Journal of the American Dietetic

$505 \quad$ Association, 106(4), 543-549.

506 30. Rolls, B. J., Roe, L. S., \& Meengs, J. S. (2007). The effect of large portion sizes

507 on energy intake is sustained for 11 days. Obesity (Silver Spring, Md.), 15(6),

$508 \quad 1535-1543$.

509 31. Spence, M., Lahteenmaki, L., Stefan, V., Livingstone, M. B., Gibney, E. R., \&

510 Dean, M. (2015). Quantifying consumer portion control practices. A cross-

511 sectional study. Appetite, 92, 240-246.

512 32. Spence M., Livingstone M. B., Hollywood L. E., Gibney E. R., O'Brien S. A.,

513 Pourshahidi L. K., et al. (2013). A qualitative study of psychological, social and

514 behavioral barriers to appropriate food portion size control. The international

$515 \quad$ journal of behavioral nutrition and physical activity, 10, 92. 
33. The Nutritional Epidemiology Group, Centre for Epidemiology and Biostatistics, University of Leeds. The UK Women's Cohort Study. (n.d.). http://dapatoolkit.mrc.ac.uk/documents/en/sna/snackingquestionnaire.pdf. Accessed 20.03.2012.

34. Tuorila, H., Huotilainen, A., Lähteenmäki, L., Ollila, S., Tuomi-Nurmi, S., \& Urala, N. (2008). Comparison of affective rating scales and their relationship to variables reflecting food consumption. Food Quality and Preference, 19(1), 51-61.

35. Vermeer, W. M., Steenhuis, I. H., \& Seidell, J. C. (2010). Portion size: a qualitative study of consumers' attitudes toward point-of-purchase interventions aimed at portion size. Health education research, 25(1), 109-120.

36. Wakimoto, P., \& Block, G. (2001). Dietary intake, dietary patterns, and changes with age an epidemiological perspective. The Journals of Gerontology Series A: Biological Sciences and Medical Sciences, 56(suppl 2), 65-80.

37. Wansink, B. (2004). Environmental factors that increase the food intake and consumption volume of unknowing consumers. Annual Review of Nutrition, 24, 455-479.

38. Wansink, B., \& Chandon, P. (2006). Can "low-fat" nutrition labels lead to obesity? Journal of Marketing Research, 43(4), 605-617.

39. Wilkinson, L. L., Hinton, E. C., Fay, S. H., Ferriday, D., Rogers, P. J., \& Brunstrom, J. M. (2012). Computer-based assessments of expected satiety predict behavioural measures of portion-size selection and food intake. Appetite, 59(3), 933-938.

40. Zlatevska, N., Dubelaar, C., \& Holden, S. S. (2014). Sizing up the effect of portion size on consumption: a meta-analytic review. Journal of Marketing, 78(3), $140-154$. 
554 Table 1 Demographic details and characteristics of the study sample

\begin{tabular}{|c|c|c|c|}
\hline & & \multicolumn{2}{|c|}{ Sample $(\%)$} \\
\hline & & $\begin{array}{c}\text { IoI } \\
(\mathrm{n}=1012)\end{array}$ & $\begin{array}{c}\text { DK } \\
(n=1063)\end{array}$ \\
\hline \multirow[t]{2}{*}{ Sex } & Male & 48 & 47 \\
\hline & Female & 52 & 53 \\
\hline \multirow[t]{4}{*}{ Age } & $18-29$ yrs & 27 & 14 \\
\hline & $30-49$ yrs & 38 & 35 \\
\hline & $50-64$ yrs & 20 & 33 \\
\hline & $65+\mathrm{yrs}$ & 15 & 17 \\
\hline \multirow[t]{5}{*}{ Body mass index ${ }^{\mathrm{a}}$} & $<18.5 \mathrm{~kg} / \mathrm{m}^{2}$ & 4 & 2 \\
\hline & $18.5-24.9 \mathrm{~kg} / \mathrm{m}^{2}$ & 48 & 44 \\
\hline & $25-29.9 \mathrm{~kg} / \mathrm{m}^{2}$ & 29 & 34 \\
\hline & $>29.9 \mathrm{~kg} / \mathrm{m}^{2}$ & 16 & 18 \\
\hline & Unknown & 3 & 3 \\
\hline \multirow[t]{4}{*}{ Highest education level } & Basic school & 27 & 10 \\
\hline & A-levels (secondary school) & 32 & 32 \\
\hline & Professional training & 20 & 35 \\
\hline & University level & 22 & 24 \\
\hline \multirow[t]{4}{*}{ Occupation status } & Employed full-time (>30h per week) & 49 & 57 \\
\hline & Employed part-time ( $\leq 29$ h per week) & 12 & 6 \\
\hline & Full-time homemaker & 11 & 1 \\
\hline & Unemployed & 11 & 7 \\
\hline
\end{tabular}




\begin{tabular}{lcc} 
Student & 6 & 7 \\
Retired & 12 & 22 \\
\hline
\end{tabular}

555

556

557

558

559

560

561

562

563

564

565

566

567

568

569

570

571

572

573

574

575

576

577

578

579

580

581

IoI $=$ Island of Ireland, DK = Denmark

${ }^{a}$ Based on self-reported height and weight of (a) pizza, (b) vegetable soup, (c) chicken salad, and (d, e, f, g) the pork meal (a)

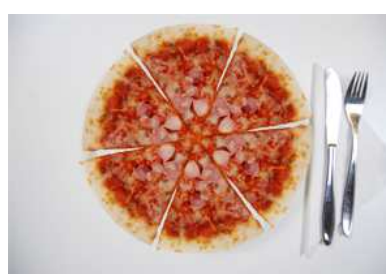

(d) (b)

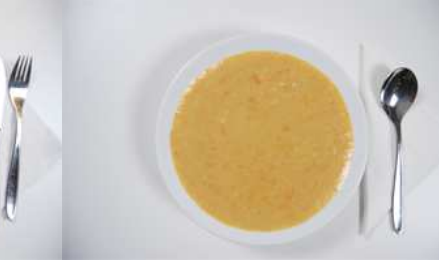

(e)

Figure 1 (A 1.5 or 2-column fitting image; no additional charge for colour please) Largest portion sizes

(c)

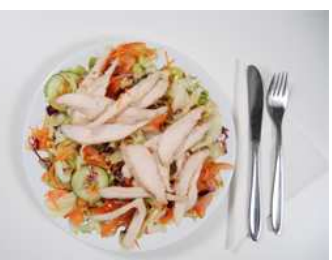

(f)

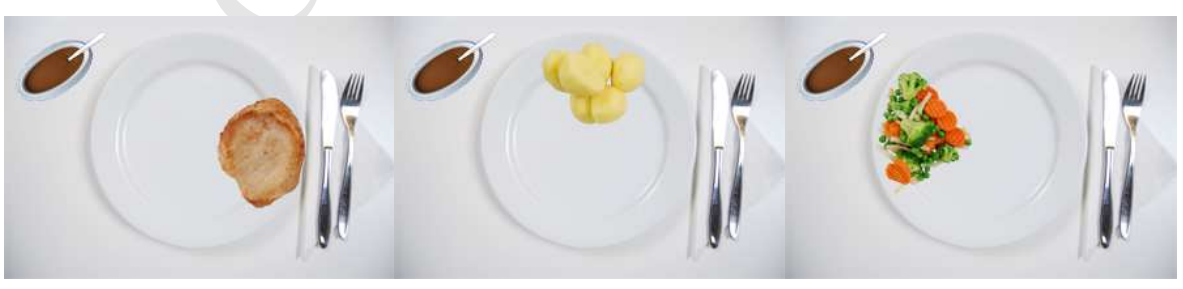

(g) 


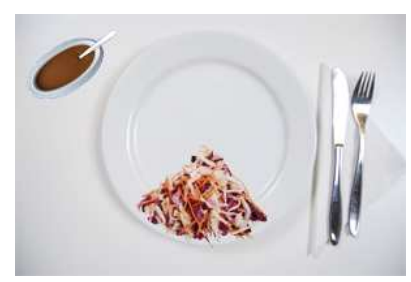

584

585

586

587

588

589

590

591

592

593

594

595

596

597 Table 2 Mean (SD) response and possible mean range for Island of Ireland and Denmark separately

\begin{tabular}{|c|c|c|c|c|c|}
\hline \multirow{2}{*}{$\begin{array}{l}\text { Variables } \\
\text { (number of items) }\end{array}$} & \multirow{2}{*}{$\begin{array}{l}\text { Possible mean range } \\
\quad \text { (end points) }\end{array}$} & \multicolumn{2}{|r|}{ IoI } & \multicolumn{2}{|c|}{ DK } \\
\hline & & $\mathrm{n}$ & $\begin{array}{c}\text { Mean (SD) } \\
\text { response or } \\
\text { number of } \\
\text { participants }\end{array}$ & $\mathrm{n}$ & $\begin{array}{c}\text { Mean }(\mathrm{SD}) \\
\text { response or } \\
\text { number of } \\
\text { participants }\end{array}$ \\
\hline \multicolumn{6}{|l|}{ Physiological variables } \\
\hline $\begin{array}{l}\text { Hunger*** } \\
\text { (1 item) }\end{array}$ & $\begin{array}{c}1-7 \\
\text { Not hungry at all- } \\
\text { extremely hungry }\end{array}$ & 1012 & $2.9(1.8)$ & 1063 & $2.4(1.6)$ \\
\hline $\begin{array}{l}\text { Thirst** } \\
\text { (1 item) }\end{array}$ & $\begin{array}{c}1-7 \\
\text { Not thirsty at all-extremely } \\
\text { thirsty }\end{array}$ & 1012 & $3.0(1.8)$ & 1063 & $3.2(1.6)$ \\
\hline \multicolumn{6}{|l|}{ Sociodemographic variables } \\
\hline Sex (male/female) & - & 1012 & $484 / 528$ & 1063 & $499 / 564$ \\
\hline $\operatorname{Age}^{* * *}$ & - & 1012 & $43.2(16.7)$ & 1063 & $48.3(14.7)$ \\
\hline $\begin{array}{l}\text { Body mass index** } \\
\text { (Self-reported height and } \\
\text { weight) }\end{array}$ & - & 1012 & $25.4(5.2)$ & 1063 & $26.2(5.3)$ \\
\hline \multicolumn{6}{|l|}{ Pizza variables } \\
\hline $\begin{array}{l}\text { Pizza portion size } * * * \\
(1 \text { item })\end{array}$ & $\begin{array}{c}1-6 \\
130-792 \mathrm{kcal} \\
\end{array}$ & 1012 & $1938(854)$ & 1044 & $2152(795)$ \\
\hline
\end{tabular}




\begin{tabular}{|c|c|c|c|c|c|}
\hline $\begin{array}{l}\text { Expected fillingness } \\
(1 \text { item })\end{array}$ & $\begin{array}{c}1-7 \\
\text { Not at all filling-extremely } \\
\text { filling }\end{array}$ & 1012 & $4.5(1.8)$ & 1063 & $4.5(1.6)$ \\
\hline $\begin{array}{l}\text { Liking*** } \\
(1 \text { item })\end{array}$ & $\begin{array}{l}1-7 \\
\text { Strongly dislike-strongly } \\
\text { like }\end{array}$ & 997 & $4.2(1.9)$ & 1062 & $5.0(1.7)$ \\
\hline $\begin{array}{l}\text { Expected healthfulness*** } \\
(1 \text { item })\end{array}$ & $\begin{array}{l}\text { 1-7 } \\
\text { Not healthy at all- } \\
\text { extremely healthy }\end{array}$ & 1012 & $2.9(1.7)$ & 1063 & $2.4(1.2)$ \\
\hline $\begin{array}{l}\text { Food familiarity*** } \\
\text { (1 item) }\end{array}$ & $\begin{array}{c}1-7 \\
\text { Never-once a day }\end{array}$ & 1012 & $5.1(1.4)$ & 1063 & $5.5(0.8)$ \\
\hline $\begin{array}{l}\text { Vegetable soup variables } \\
\text { Vegetable soup portion size } \\
(1 \text { item })\end{array}$ & $\begin{array}{c}1-6 \\
30-180 \mathrm{kcal}\end{array}$ & 1012 & $527(159)$ & 1045 & $531(192)$ \\
\hline $\begin{array}{l}\text { Expected fillingness } * * * \\
(1 \text { item })\end{array}$ & $\begin{array}{c}1-7 \\
\text { Not at all filling-extremely } \\
\text { filling }\end{array}$ & 1012 & $4.7(1.6)$ & 1063 & $4.2(1.6)$ \\
\hline $\begin{array}{l}\text { Liking } \\
\quad(1 \text { item })\end{array}$ & $\begin{array}{c}1-7 \\
\text { Strongly dislike-strongly } \\
\text { like }\end{array}$ & 1007 & $5.0(1.5)$ & 1057 & $5.18(1.8)$ \\
\hline $\begin{array}{l}\text { Expected healthfulness* } \\
(1 \text { item })\end{array}$ & $\begin{array}{l}1-7 \\
\text { Not healthy at all- } \\
\text { extremely healthy }\end{array}$ & 1012 & $5.9(1.2)$ & 1063 & $6.0(1.1)$ \\
\hline $\begin{array}{l}\text { Food familiarity**** } \\
(1 \text { item })\end{array}$ & $\begin{array}{c}1-7 \\
\text { Never-once a day } \\
\end{array}$ & 1012 & $4.5(1.3)$ & 1063 & $5.6(1.0)$ \\
\hline $\begin{array}{l}\text { Chicken salad variables } \\
\text { Chicken salad portion size } \text { ( } * * *^{*} \\
(1 \text { item })\end{array}$ & $\begin{array}{c}1-6 \\
46-276 \mathrm{kcal}\end{array}$ & 1012 & $787(242)$ & 1044 & $703(255)$ \\
\hline $\begin{array}{l}\text { Expected fillingness } * * * \\
(1 \text { item })\end{array}$ & $\begin{array}{l}1-7 \\
\text { Not at all filling-extremely } \\
\text { filling }\end{array}$ & 1012 & $4.4(1.6)$ & 1063 & $5.0(1.3)$ \\
\hline $\begin{array}{l}\text { Liking*** } \\
(1 \text { item })\end{array}$ & $\begin{array}{c}1-7 \\
\text { Strongly dislike-strongly } \\
\text { like }\end{array}$ & 1008 & $4.8(1.6)$ & 1057 & $6.0(1.3)$ \\
\hline $\begin{array}{l}\text { Expected healthfulness } \\
\text { (1 item) }\end{array}$ & $\begin{array}{l}\quad 1-7 \\
\text { Not healthy at all- } \\
\text { extremely healthy }\end{array}$ & 1012 & $6.0(1.2)$ & 1063 & $6.0(1.1)$ \\
\hline $\begin{array}{l}\text { Food familiarity**** } \\
(1 \text { item) }\end{array}$ & $\begin{array}{c}1-7 \\
\text { Never-once a day } \\
\end{array}$ & 1012 & $4.5(1.3)$ & 1063 & $4.9(1.1)$ \\
\hline $\begin{array}{l}\text { Pork meal variables } \\
\text { Pork meal portion size } \\
\left(3-4 \text { items }^{\mathrm{a}}\right)\end{array}$ & $\begin{array}{c}1-6 \\
146-408 \mathrm{kcal}\end{array}$ & 1012 & $1205(226)$ & 1062 & $1251(226)$ \\
\hline $\begin{array}{l}\text { Expected fillingness } \\
\quad(1 \text { item })\end{array}$ & $\begin{array}{c}1-7 \\
\text { Not at all filling-extremely } \\
\text { filling }\end{array}$ & 1012 & $6.0(1.9)$ & 1063 & $6.1(1.0)$ \\
\hline $\begin{array}{l}\text { Liking** } \\
(1 \text { item })\end{array}$ & $\begin{array}{c}1-7 \\
\text { Strongly dislike-strongly } \\
\text { like }\end{array}$ & 1006 & $5.3(1.5)$ & 1060 & $5.5(1.6)$ \\
\hline $\begin{array}{l}\text { Expected healthfulness } * * * \\
(1 \text { item })\end{array}$ & $\begin{array}{c}1-7 \\
\text { Not healthy at all- } \\
\text { extremely healthy }\end{array}$ & 1012 & $5.4(1.3)$ & 1063 & $4.8(1.3)$ \\
\hline $\begin{array}{l}\text { Food familiarity*** } \\
(1 \text { item })\end{array}$ & $\begin{array}{c}1-7 \\
\text { Never-once a day }\end{array}$ & 1012 & $4.3(1.3)$ & 1063 & $5.0(1.2)$ \\
\hline \multicolumn{6}{|l|}{ Psychological variables } \\
\hline $\begin{array}{l}\text { General Health Interest }{ }^{\mathrm{b} * * *} \\
(7 \text { items })\end{array}$ & $\begin{array}{c}1-7 \\
\begin{array}{c}\text { Strongly disagree/strongly } \\
\text { agree }^{c}\end{array}\end{array}$ & 1012 & $4.4(1.2)$ & 1063 & $4.8(1.2)$ \\
\hline $\begin{array}{l}\text { Cognitive restraint }{ }^{\mathrm{de} * * *} \\
(6 \text { items })\end{array}$ & $1-4^{f}$ & 1012 & $2.2(0.7)$ & 1063 & $2.3(0.6)$ \\
\hline
\end{tabular}




\begin{tabular}{lccccc}
\hline $\begin{array}{c}\text { Uncontrolled eating } \\
(9 \text { items })\end{array}$ & $1-4^{\mathrm{f}}{ }^{\mathrm{f}}$ & 1011 & $2.1(0.6)$ & 1063 & $2.0(0.6)$ \\
\hline $\begin{array}{c}\text { Emotional eating } \\
(3 \text { items })\end{array}$ & $\begin{array}{c}1-4 \\
\text { dh }\end{array}$ & 1012 & $2.1(0.9)$ & 1063 & $1.7(0.8)$ \\
\hline $\begin{array}{c}\text { Definitely false-definitely } \\
\text { true }^{\mathrm{c}}\end{array}$ & & & & \\
\hline
\end{tabular}

598

599

600

601

602

603

604

605

606

607

608

609

610

611

612

613

614

615

616

617

618

619

620

Significantly different between studies $\left(p<0.05^{*} ;<0.01 * *,<0.001 * * *\right)$; IoI = Island of Ireland, DK =

Denmark

${ }^{\mathrm{a}}$ The multi-component pork meal, where meal kilocalories were computed as a summation of its component kilocalories

${ }^{\mathrm{b}}$ From the General Heath Interest scale (Roininen, Lahteenmaki, \& Tuorila, 1999)

${ }^{\mathrm{c}}$ Higher scores indicative of greater levels of the construct

${ }^{\mathrm{d}}$ From the Three-Factor Eating Questionnaire Revised 18 item version (de Lauzon et al., 2004)

${ }^{\mathrm{e}}$ Reliability $(\alpha)=0.82$ and 0.76 for IoI and DK, respectively

${ }^{\mathrm{f}}$ The response alternatives measured how true, likely or frequent certain food control behaviors were;

higher scores indicative of greater levels of the construct

${ }^{\mathrm{g}}$ Reliability $(\alpha)=0.87$ and 0.85 for IoI and DK, respectively

${ }^{\mathrm{h}}$ Reliability $(\alpha)=0.87$ and 0.85 for IoI and DK, respectively (1) 


\begin{tabular}{llllllll}
\hline df & 4,932 & 4,974 & 4,939 & 4,970 & 4,944 & 4,966 & 4,940 \\
\hline
\end{tabular}

621

$622 * * * p<0.01, * * * p<0.001 ;$ IoI $=$ Island of Ireland, DK = Denmark

$623{ }^{a}$ The multi-component pork meal, where meal kilocalories were computed as a summation of its

624 component kilocalories

$625{ }^{\mathrm{b}}$ Including hunger and thirst

$626{ }^{\mathrm{c}}$ Including sex, age and body mass index

$627{ }^{\mathrm{d}}$ Including cognitive restraint, uncontrolled eating, emotional eating and General Health Interest

$628{ }^{\mathrm{e}}$ Including expected fillingness, expected healthfulness, liking and food familiarity

630

631

632

633

634

635

636

637

638

639

640

641

642

643 Table 4 Standardized coefficients ( $\beta$ ) for the final regression models (per country)

\begin{tabular}{|c|c|c|c|c|c|c|c|c|}
\hline \multirow[t]{2}{*}{ Independent variables } & \multicolumn{2}{|c|}{ Pizza portion size (kcal) } & \multicolumn{2}{|c|}{$\begin{array}{l}\text { Vegetable soup portion } \\
\text { size (kcal) }\end{array}$} & \multicolumn{2}{|c|}{$\begin{array}{l}\text { Chicken salad portion } \\
\text { size (kcal) }\end{array}$} & \multicolumn{2}{|c|}{$\begin{array}{c}\text { Pork meal portion size } \\
\left(_{(\text {kcal })^{\mathrm{a}}}\right.\end{array}$} \\
\hline & $\begin{array}{c}\mathrm{IoI} \\
(\mathrm{n}=946)\end{array}$ & $\begin{array}{c}\mathrm{DK} \\
(\mathrm{n}=988)\end{array}$ & $\begin{array}{c}\mathrm{IoI} \\
(\mathrm{n}=953)\end{array}$ & $\begin{array}{c}\text { DK } \\
(\mathrm{n}=984)\end{array}$ & $\begin{array}{c}\mathrm{IoI} \\
(\mathrm{n}=958)\end{array}$ & $\begin{array}{c}\text { DK } \\
(\mathrm{n}=980)\end{array}$ & $\begin{array}{c}\text { IoI } \\
(\mathrm{n}=954)\end{array}$ & $\begin{array}{c}\text { DK } \\
(\mathrm{n}=1008)\end{array}$ \\
\hline $\begin{array}{l}\text { Step 1: Physiological } \\
\text { Hunger } \\
\text { Thirst }^{\mathrm{b}}\end{array}$ & $\begin{array}{c}.133^{* * *} \\
-.10^{* * *}\end{array}$ & $\begin{array}{l}-.01 \\
-.03\end{array}$ & $\begin{array}{l}.09^{*} \\
-.09^{*}\end{array}$ & $\begin{array}{r}.06 \\
-.04\end{array}$ & $\begin{array}{l}.05 \\
-.08\end{array}$ & $\begin{array}{c}.04 \\
-.02\end{array}$ & $\begin{array}{l}-.01 \\
-.05\end{array}$ & $\begin{array}{l}.01 \\
-.02\end{array}$ \\
\hline $\begin{array}{l}\text { Step 2: Sociodemographic } \\
\text { Sex } \\
\text { Age } \\
\text { Body mass index } \\
\end{array}$ & $\begin{array}{l}-.28^{* * * *} \\
-.07^{*} \\
-.02 \\
\end{array}$ & $\begin{array}{l}-.22^{* * *} \\
-.21^{* * *} \\
.07^{*}\end{array}$ & $\begin{array}{l}-.29 * * * \\
.01 \\
-.01 \\
\end{array}$ & $\begin{array}{l}-.12^{* * *} \\
-.07^{*} \\
.11^{* * *}\end{array}$ & $\begin{array}{l}-.25^{* * * *} \\
-.02 \\
-.00 \\
\end{array}$ & $\begin{array}{l}-.25^{* * * *} \\
-.10^{* * *} \\
.11^{* * * *}\end{array}$ & $\begin{array}{c}-.28 * * * \\
-.04 \\
.04 \\
\end{array}$ & $\begin{array}{l}-.31^{* * *} \\
-.13^{* * *} \\
.08^{* *}\end{array}$ \\
\hline $\begin{array}{l}\text { Step 3: Psychological } \\
\text { Cognitive restraint } \\
\text { Uncontrolled eating }^{\mathrm{e}} \\
\text { Emotional eating } \\
\text { General health interest }^{\mathrm{f}} \\
\text { Gen }^{\mathrm{e}}\end{array}$ & $\begin{array}{l}-.06 \\
.11 * * \\
.15^{* * * *} \\
-.05 \\
\end{array}$ & $\begin{array}{l}-.11^{* * *} \\
.13^{* * * *} \\
-.02 \\
.04 \\
\end{array}$ & $\begin{array}{l}-.08^{*} \\
.17^{* * *} \\
.09^{*} \\
.04 \\
\end{array}$ & $\begin{array}{l}-.14^{* * * *} \\
.14^{* * * *} \\
-.05 \\
.08 * \\
\end{array}$ & $\begin{array}{l}-.07 \\
.15^{* * *} \\
.12^{* * *} \\
.11^{* *}\end{array}$ & $\begin{array}{l}-.13^{* * * *} \\
.24^{* * * *} \\
-.02 \\
.08^{*} \\
\end{array}$ & $\begin{array}{c}-.05 \\
.31 * * * \\
.00 \\
.05 \\
\end{array}$ & $\begin{array}{l}-.17 * * * \\
.18 * * * \\
-.03 \\
-.04 \\
\end{array}$ \\
\hline $\begin{array}{l}\text { Step 4: Food-related } \\
\text { Expected fillingness }^{\mathrm{b}} \\
\text { Expected healthfulness }^{\mathrm{b}}\end{array}$ & $\begin{array}{l}.06 * \\
-.01\end{array}$ & $\begin{array}{l}.04 \\
-.05\end{array}$ & $\begin{array}{l}-.05 \\
.12^{* * *}\end{array}$ & $\begin{array}{l}-.06 \\
.10 * *\end{array}$ & .02 & $\begin{array}{l}-.03 \\
.08\end{array}$ & $.24^{* * * *}$ & $\begin{array}{l}.01 \\
.06\end{array}$ \\
\hline
\end{tabular}




\section{ACCEPTED MANUSCRIPT}

\begin{tabular}{|c|c|c|c|c|c|c|c|c|}
\hline Liking ${ }^{\mathrm{b}}$ & $.28^{* * * *}$ & $.25^{* * *}$ & $.27^{* * * *}$ & $.29^{* * * *}$ & $.23^{* * * *}$ & $.10^{*}$ & $.15^{* * *}$ & $.14^{* * * *}$ \\
\hline Food familiarity ${ }^{\mathrm{b}}$ & $.15^{* * *}$ & .05 & .01 & .06 & -.02 & .02 & -.05 & -.02 \\
\hline Final model $\left(R_{a d j}^{2}\right)$ & .43 & .29 & .21 & .16 & .14 & .16 & .28 & .27 \\
\hline Model F & $56.17 * * *$ & $31.27 * * *$ & $20.99 * * *$ & $14.96 * * *$ & $12.46 * * *$ & $15.32 * * *$ & 29.91*** & $29.57 * * *$ \\
\hline$\overline{d f}$ & 13,932 & 13,974 & 13,939 & 13,970 & 13,944 & 13,966 & 13,940 & 13,994 \\
\hline
\end{tabular}

644

$645 * p \leq 0.05 ; * * p<0.01,{ }^{* * *} p<0.001$; bold text highlights significance; IoI = Island of Ireland, DK =

646 Denmark

$647{ }^{\text {a }}$ The multi-component pork meal, where meal kilocalories were computed as a summation of its

648 component kilocalories

$649{ }^{\mathrm{b}}$ One item measured on a 7-point Likert scale; higher scores indicative of greater levels of the construct

$650{ }^{\mathrm{c}} 0=$ males, $1=$ female

$651{ }^{\mathrm{d}}$ Based on self-reported height and weight

$652{ }^{\mathrm{e}} \mathrm{A}$ mean of 6 items (cognitive restraint), 9 items (uncontrolled eating) and 3 items (emotional eating)

653 measured on a 4-point Likert scale taken from the Three-Factor Eating Questionnaire Revised 18 item

654 version (de Lauzon et al., 2004); higher scores indicative of greater levels of the construct

$655{ }^{\mathrm{f}}$ A mean of 7 items measured on a 7-point Likert scale taken from the General Heath Interest scale

656 (Roininen, Lahteenmaki, \& Tuorila, 1999) ; higher scores indicative of greater levels of the construct 